\title{
PENERAPAN KEPEMIMPINAN INSTRUKSIONAL DALAM KEPEMIMPINAN KEPALA MADRASAH PADA MAN 2 BULUKUMBA
}

\author{
RINA SULAEHA \\ Pascasarjana UIN Alauddin Makassar \\ Jl. Sultan Alauddin No. 36 Samata-Gowa \\ Email: rina.sulaeha@gmail.com
}

\begin{abstract}
:
The purpose of this study was to find out how the strategies and opportunities and challenges of instructional leadership of Madrasah Aliyah Negeri 2 Bulukumba Headmaster. Research is a descriptive qualitative research with a pedagogical, sociological and philosophical approach. The data collection techniques used are observation, interview and documentation. The results of the study found that 1) Instructional Leadership of Madrasah Aliyah Negeri 2 Bulukumba went well but the need for policy innovations is to present the campus in Madrasah internal supervision and training activities, 2) Instructional Madrasah Head Instructional Strategy that is implemented is to maximize supervision of Madrasah scope, training the scope of Madrasas and involving teachers and education staff training/workshops/seminars to improve the quality of education in Madrasas in quantity but not yet maximally in quality because internal training and supervision has not been maximized because it has not involved experts in their fields, namely the campus, 3) Opportunities and challenges of the Head Madrasah Aliyah Negeri 2 Bulukumba in implementing instructional leadership are 1) Opportunities: (a) Maximum support for teaching and educational staff in order to improve the quality of education, (b) Madrasas have partners who can work together to To improve the quality of education in Madukah Aliyah Negeri 2 Bulukumba, (c) Budgeting for increasing human resource competency in Madarasah Aliyah Negeri 2 Bulukumba. 2) Challenges: (a) The portion of the budget is divided so that it cannot maximally develop and improve HR in Madrasahs, (b) Mitra MadarasahAliyah Negeri 2 Bulukumba has not formed a partnership with the campus which is considered to be able to improve the quality of human resources, (c) Educators and education staff have not maximally made individual efforts to improve their performance.
\end{abstract}

Keywords: Instructional Leadership, Instructional Strategy, Human Resource Competency

\section{PENDAHULUAN}

Kepala madrasah sebagai pemimpin pendidikan, dilihat dari status dan cara pengangkatannya tergolong pemimpin resmi, "formal leader", atau "status leader". Kedudukannya sebagai "status leader" bisa meningkat pula menjadi "functional leader", atau "operational leader", tergantung pada prestasi dan kemampuannya di 
dalam memainkan peranan sebagai pemimpin pendidikan pada madrasah yang telah diserahkan pertanggungan jawab kepadanya. (Soekarto, dkk, 1983;77).

Pada sebuah madrasah, kepala madrasah adalah bapak sekaligus sebagai ibu bagi semua guru yang bertugas di madrasah tersebut. Hal ini memberikan konsekuensi yang logis bahwa seorang kepala madrasah haruslah mempunyai tingkat kemampuan lebih dibandingkan dengan bawahannya khususnya guru sehingga dapat mengontribusi segala kebutuhan guru-guru yang bersifat fisik dan bahkan terkadang bersifat psikis. Hal ini berkaitan dengan posisinya sebagai pemimpin madrasah dan manajer dari organisasi madrasah. Sehingga peningkatan kemampuan tersebut sebenarnya sebagai upaya untuk melengkapi diri agar dapat melaksanakan tugas sebagaimana mestinya. Kewajiban dan tugas kepala madrasah merupakan konsekuensi yang sangat berat serta penuh tanggung jawab. Karena itu, jika tidak memiliki kemampuan untuk memimpin dan mengelola organisasi madrasah, maka visi dan misi madrasah tidak mungkin tercapai secara maksimal. (Saroni, 2006:48).

Kualitas seorang pemimpin sangat menentukan keberhasilan lembaga yang dipimpinnya, termasuk di dalamnya lembaga pendidikan karena kepemimpinan yang sukses itu mampu mengelola lembaga yang dipimpin, mampu mengantisipasi perubahan, mampu mengoreksi kekurangan dan kelemahan serta sanggup membawa lembaga yang dipimpin pada tujuan yang ditetapkan. Sehubungan dengan itu maka pemimpin merupakan kunci sukses bagi organisasi. (Kartini, 2010:1).

Kualitas dan perilaku kepala madrasah hendaknya mencakup hal-hal berikut: 1). Visi yang kuat tentang masa depan madrasah dan dorongan terhadap semua staf atau karyawan untuk berkarya menuju perwujudan visi tersebut. 2). Harapan yang tinggi terhadap prestasi peserta didik dan kinerja staf. 3). Pengamatan terhadap guru di kelas dan pemberian balikan positif dan konstruktif dalam rangka pemecahan masalah dan peningkatan pembelajaran. 4). Dorongan untuk memanfaatkan waktu pembelajaran secara efisien dan merancang prosedur untuk mengurangi kekacauan. 5). Pemanfaatan sumber-sumber material dan personil secara kreatif. 6). Pemantauan terhadap prestasi didik peserta secara individual dan kolektif dan memanfaatkan informasi untuk membimbing perencanaan instruksional. (Sulistyorini, 2006:131).

Sekolah yang berada di Indonesia harus dapat melaksanakan fungsi dan tugasnya untuk mewujudkan tujuan nasional yang tercantum dalam Undang-undang RI No. 20 tahun 2003 tentang Sistem Pendidikan Nasional beserta penjelasannya Bab II Pasal 3 yang berbunyi:

Pendidikan Nasional berfungsi mengembangkan kemampuan dan membentuk watak serta peradaban bangsa yang bermartabat dalam rangka mencerdaskan kehidupan bangsa, bertujuan untuk berkembangnya potensi peserta didik agar menjadi manusia yang beriman dan bertaqwa kepada Tuhan 
Yang Maha Esa, berakhlak mulia, sehat, mandiri dan menjadi warga negara yang demokratis serta bertanggung jawab."

Kepala madrasah sebagai pemimpin pendidikan pada tingkat madrasah memiliki peranan yang cukup besar dalam mengembangkan kualitas pendidikan di madrasah yang menjadi tanggung jawabnya. Tumbuh kembangnya semangat kerja guru dan karyawan tergantung pada kinerja kepala madrasah, komunikasi antar pribadi kepala madrasah, serta kemampuan dalam memimpin madrasah (Abdullah Munir, 2008:16). Kepemimpinan kepala madrasah yang efektif akan dapat bekerja sesuai dengan konteksnya, yaitu mampu memberikan visi, menciptakan gambaran yang besar, menetapkan tujuan yang jelas dan disetujui bersama, serta memonitor dan menganalisis prestasi serta mampu mengembangkan prestasi para pengikut, yaitu dengan memberikan pengarahan dan panduan, melatih dan membimbing serta memberikan umpan balik.(Munir, 2008:16) Dengan ditingkatkannya kualitas pendidikan diharapkan guru dan pegawai akan lebih mampu menjadi tenaga kependidikan yang dapat mengemban tugasnya dengan baik. Pekerjaan yang dilaksanakan dengan baik akan disertai dengan pendidikan dan keterampilan yang sesuai akan mendorong kemajuan setiap usaha, yang pada gilirannya akan meningkatkan pendapatan baik perorangan, kelompok, maupun nasional. Peran setiap variabel terhadap tingkat serta naik turunnya produktivitas tidak tetap, melainkan dinamis (Mulyasa, 2007:135).

Kepala madrasah adalah seorang tenaga fungsional guru yang diberi tugas untuk memimpin suatu sekolah dimana diselenggarakan proses belajar mengajar, atau tempat dimana terjadi interaksi antara guru yang memberi pelajaran dan murid yang menerima pelajaran (Wahjo Sumidjo, 2003: 83). Kepemimpinan kepala sekolah terlihat dari kemampuannya menggerakkan dan mendorong kinerja guru untuk meningkatkan pencapaian tujuan pembelajaran. Kepala sekolah bertanggung jawab mengarahkan apa yang baik bagi pegawainya dan dia sendiri harus berbuat baik dan bijaksana. Pemimpin harus menjadi contoh, sabar, konsisten dan penuh pengertian sesuai dengan motto Ki Hadjar Dewantara:" Ing Ngarsa Sung Tulada, Ing Madya Mangan Karsa, Tutwuri Handayani (di depan menjadi tauladan, di tengah membangun semangat dan di belakang memberikan pengaruh). (Wahjo Sumidjo, 2003: 83).

Dalam peraturan Menteri Agama Republik Indonesi No.58 tahun 2017 disebutkan bahwa pada pasal 3 kepala madrasah memiliki tugas manajerial, mengembangkan kewirausahaan, dan melakukan supervisi kepada guru dan tenaga kependidikan serta kepala madrasah dapat melaksanakan tugas pembelajaran atau pembimbingan untuk memenuhi kebutuhan guru Madrasah.

Kepemimpinan instruksional kepala Madrasah adalah bagian dari tanggung jawab sebagai pemimpin di Madrasah. Kepala madrasah menjadi solusi setiap permasalahan bawahannya khususnya bagi guru yang mengalami masalah dalam mengembangkan pembelajaran di kelas. (Syarwan Ahmad, 2013:98). Maka dapat 
disimpulkan bahwa kepemimpinan instruksional merupakan keharusan yang harus dihadirkan di dalam kepemimpinan kepala madrasah.

Berbagai fenomena yang terjadi seperti terdapat beberapa guru yang terlambat menyelesaikan administrasi pembelajaran, penggunaan teknologi seperti komputer masih ada yang belum mahir menggunakannya dan hasil belajar peserta didik yang belum maksimal karena masih terdapat peserta didik yang mengikuti remedial.

Berdasarkan uraian tersebut, maka pokok masalah pada penelitian ini adalah “Bagaimana Penerapan kepemimpinan Instruksional pada Kepemimpinan Kepala Madrasah 2 Bulukumba”. Pokok masalah tersebut kemudian diturunkan dalam sub masalah sebagai berikut: 1) Bagaimana kepemimpinan instruksional Kepala di Madrasah Aliyah Negeri 2 Bulukumba? 2) Bagaimana strategi Kepala Madrasah dalam menerapkan kepemimpinan instruksional di Madrasah Aliyah Negeri 2 Bulukumba? 3) Apa peluang dan tantangan Kepala Madrasah dalam menerapkan kepemimpinan instruksional di Madrasah Aliyah Negeri 2 Bulukumba?

Kepala madrasah merupakan salah satu faktor yang dapat mendorong untuk dapat mewujudkan visi, misi, dan tujuan serta sasaran madrasah melalui progamprogam yang dilaksanakan secara terencana dan bertahap. Oleh karena itu, kepala madrasah dituntut memiliki kemampuan manajemen dan kepemimpinan yang tangguh agar mampu mengambil keputusan dan prakarsa untuk meningkatkan mutu madrasah sehingga akan memberikan dampak positif dan perubahan mendasar terhadap eksistensi madrasah. Dampak tersebut antara lain terhadap efektifitas pendidikan, kepemimpinan sekolah yang kuat, pengelolaan tenaga kependidikan yang efektif, budaya mutu, teamwork yang kompak, cerdas, dan dinamis, kemandirian, partisipasi warga sekolah dan masyarakat, keterbukaan (transparansi) manajemen, kemauan untuk berubah (psikologis dan fisik), evaluasi dan perbaikan berkelanjutan, responsif dan antisipatif terhadap kebutuhan, akuntabilitas dan sustainabilitas (Mulysa, 2013:89).

Kepala madrasah merupakan personil yang bertanggung jawab terhadap seluruh kegiatan madrasah. Dia memiliki wewenang dan tanggung jawab penuh untuk menyelenggarakan seluruh kegiatan pendidikan dalam lingkungan madrasahnya. Kepala madrasah selaku pimpinan dalam lembaga pendidikan islam ini diharapkan dapat menjalankan tugas dengan baik dan mampu mengembangkan diri bersama mitra kerjanya untuk mencapai kemajuan madrasah (Abdullah Munir, 2008:13).

Untuk kepentingan tersebut kepala sekolah harus mampu memobilisasi sumber daya sekolah dalam kaitannya dengan perencanaan dan evaluasi, pengembangan kurikulum, pengembangan pembelajaran, pengelolaan ketenangan, pengelolaan sarana dan sumber belajar, pengelolaan keuangan Pelayanan siswa, hubungan sekolah dengan masyarakat dan penciptaan iklim sekolah (Mulyasa, 2004:182). 
Menurut Scheeren dalam Andang yang dikutip tahun 2014 mengemukakan bahwa sekolah efektif dipengaruhi antara lain: (1) kepemimpinan pembelajaran yang kuat; (2) penekanan pada memperoleh keterampilan dasar; (3) sebuah lingkungan yang aman dan rapi; (4) ekspektasi tinggi terhadap pencapaian siswa; (5) penilaian terhadap kemajuan siswa.

Kepemimpinan pembelajaran yang kuat dapat meningkatkan kualitas Iulusan. Kepemimpinan pembelajaran mencakup perilaku kepala madrasah dalam merumuskan dan mengkomunikasikan tujuan madrasah, memantau, dan memberikan umpan balik dalam pembelajaran dan menciptakan iklim akademik dan komunikasi efektif antar staf.

Kepemimpinan pembelajaran sangat cocok diterapkan di sekolah karena misi utama sekolah adalah mendidik siswa dan memberikan kesempatan untuk mendapatkan pengetahuan, keterampilan dan nilai nilai yang dibutuhkan untuk menghadapi masa depan.

Pada tingkat madrasah, kepala madrasah sebagai figur kunci dalam memajukan proses pengajaran dan pembelajaran. Terkait hal tersebut kepala madrasah mempunyai tanggung jawab dalam pengembangan program madrasah, kurikulum dan sumberdaya, termasuk memiliki tanggung jawab untuk meningkatkan profesionalitas guru. Untuk menjadikan guru yang profesional menuntut kepala lembaga pendidikan terlebih dulu harus profesional. Kepala madrasah harus memiliki skill dalam memimpin kelompok dan pendelegasian tugas dan wewenang. Kepala madrasah harus berusaha memberikan teladan dan contoh yang baik (Mulysa, 2013:119). Tidak hanya dapat memberikan perintah, namun dapat menjadi contoh bagi guru, staf dan peserta didik singkatnya bisa menjadi role model.

Menurut Keefe dan Jenkins seperti yang dikutip Supardi mengatakan bahwa kepemimpinan instruksional kepala sekolah perlu berperan memperbaiki pengajaran dan pembelajaran di sekolah dengan senantiasa memberi arahan menyediakan sumber, dan paling penting memberikan bantuan pada guru (Supardi, 2013:450)

Jabatan kepala madrasah/sekolah merupakan jabatan yang sangat berat yang menuntut kemampuan ekstra, meskipun pengangkatannya tidak dilakukan dengan sembarangan, bahkan diangkat dari guru yang sudah berpengalaman atau mungkin sudah lama menjabat sebagai wakil kepala sekolah, namun tidak dengan sendirinya membuat kepala sekolah menjadi profesional dalam melaksanakan tugas (Mulyasa, 2003:97).

\section{METODE PENELITIAN}

Metode yang digunakan adalah jenis kualitatif. Kualitatif adalah suatu prosedur penelitian yang menghasilkan data deskriptif berupa kata-kata tertulis atau lisan orang-orang dan perilaku yang dapat diamati. Pendekatan ini diarahkan pada latar dan individu secara holistik (utuh). Jadi dalam hal ini tidak boleh mengisolasi individu 
atau organisasi ke dalam variabel atau hipotesis. Pendekatan kualitatif memiliki karakteristik alami (natural serfing) sebagai sumber data langsung, deskriptif, proses lebih dipentingkan dari pada hasil. Analisis dalam penelitian kualitatif cenderung dilakukan secara analisa induktif dan makna merupakan hal yang esensial. (Lexy, 2006:4).

Penelitian ini menggunakan pendekatan pedagogik, sosiologis filosofis dan fenomenologi. Dalam penelitian ini ada dua sumber data, yaitu data primer dan data sekunder. Metode pengumpulan data yang digunakan yaitu observasi, wawancara dan dokumentasi. Data yang terkumpul kemudian dianalisis melalui tahapantahapan sebagai berikut: 1) Penetapan fokus penelitian, 2) Penyusunan temuantemuan sementara berdasarkan data yang telah terkumpul, 3) Pembuatan rencana pengumpulan data berikutnya berdasarkan temuan-temuan pengumpulan data sebelumnya., 4) Pengembangan pertanyaan-pertanyaan analitik dalam rangka pengumpulan data berikutnya dan 5) Penetapan sasaran-sasaran pengumpulan data (informasi Madrasah Aliyah Negeri, situasi, dokumen) berikutnya.

Data yang dikumpulkan kemudian diolah dan dianalisis dengan langkahlangkah sebagai berikut: 1) Reduksi data, yaitu penulis merangkum beberapa data yang dianggap penting untuk dianalisa, kemudian dimasukkan ke dalam pembahasan, 2) Penyajian data, yaitu penulis memperoleh data dan keterangan dari objek yang bersangkutan, kemudian disajikan untuk dibahas guna menemukan kebenaran-kebenaran yang hakiki, 3) Verifikasi data, yaitu penulis membuktikan kebenaran data yang dapat diukur, diperoleh melalui responden yang memahami masalah yang diajukan, dengan tujuan menghindari adanya unsur subjektifitas yang dapat mengurangi bobot kualitas tesis ini.

\section{HASIL PENELITIAN DAN PEMBAHASAN}

Observasi, wawancara dan dokumentasi telah dilakukan dan berdasarkan hasil analisis maka beberapa temuan dalam penelitian bisa diuraikan sebagai berikut:

\section{Kepemimpinan Instruksional Kepala Madrasah Aliyah Negeri 2 Bulukumba}

Kepemimpinan Instruksional Kepala Madrasah Aliyah Negeri 2 Bulukumba dapat dilihat dari koordinasi dan pengawasan dalam pembagian kerja di Madrasah khususnya yang berhubungan dengan kegiatan pembelajaran berjalan dengan baik dan melibatkan semua tenaga pendidik dan kependidikan, Kepala madrasah mampu menetapkan standar akademik dan mampu memberikan penilaian sebagai bahan evaluasi, Kepala madrasah mengumpulkan berbagai masukan sebagai langkah pengambilan keputusan dalam membangun dan mengadakan sarana prasarana pembelajaran dan fasilitas di madrasah sebagai langkah untuk mendorong iklim kerja dan pembelajaran yang kondusif dan nyaman serta kepala madrasah mampu melakukan supervisi secara berkesinambungan baik kepada tenaga pendidik atau tenaga kependidikan. 
Berdasarkan uraian tersebut maka kepemimpinan instruksional kepala madrasah Aliyah Negeri 2 Bulukumba berjalan dengan baik meskipun masih perlu ditingkatkan agar intruksional Kepala Madrasah lebih efektif lagi.

\section{Strategi kepemimpinan intruksional yang diterapkan Kepala Madrasah di Madrasah Aliyah Negeri 2 Bulukumba}

Strategi kepemimpinan intruksional yang diterapkan Kepala Madrasah di Madrasah Aliyah Negeri 2 Bulukumba dapat diketahui dari kepala madrasah melakukan supervisi secara berkala dengan melihat situasi dan kebutuhan guru, kepala madrasah memberikan dukungan melalui pelatihan baik secara internal ataupun eksternal dan kepala madrasah support terhadap pengembangan dan peningkatan skill mengajar dan administrasi pembelajaran melalui pelatihan/ workshop/ seminar yang berhubungan dengan pendidikan dan keguruan.

Beradasarkan tersebut maka peneliti dapat memberi kesimpulan bahwa kepala madrasah memaksimalkan supervisi lingkup Madrasah, pelatihan lingkup madrasah dan mengikutkan guru dan tenaga kependidikan pelatihan / workshop/ seminar untuk meningkatkan mutu pendidikan di madrasah secara kuantitas tetapi secara kualitas belum maksimal karena dalam pelatihan dan supervisi internal belum maksimal.

\section{Peluang dan tantangan kepala madrasah dalam menerapkan kepemimpinan intruksional di Madrasah Aliyah Negeri 2 Bulukumba.}

Ada beberapa peluang Kepala Madrasah Aliyah Negeri 2 Bulukumba yaitu: 1) Dukungan maksimal kepada tenaga pendidik dan kependidikan dalam rangka untuk peningkatan mutu pendidikan, 2) Madrasah memiliki mitra yang dapat bekerjasama untuk peningkatan mutu pendidikan di Madrasah Aliyah Negeri 2 Bulukumba, 3) Penganggaran peningkatan kompetensi SDM di Madarasah Aliyah Negeri 2 Bulukumba. Kemudian tantangan Kepala madrasah Aliyah Negeri 2 Bulukumba yaitu 1) Porsi anggaran terbagi sehingga tidak dapat secara maksimal dalam mengembangkan dan meningkatkan SDM di Madrasah, 2) Mitra Madarasah Aliyah Negeri 2 Bulukumba belum menjalin kemitraan dengan pihak kampus yang dinilai dapat mendorong peningkatan mutu SDM, 3) Tenaga pendidik dan tenaga kependidikan belum secara maksimal melakukan upaya secara individu untuk meningkatakan kinrjanya.

\section{Kepemimpinan Instruksional Kepala Madrasah Aliyah Negeri 2 Bulukumba.}

Hasil penelitian mengungkapkan kepemimpinan instruksional Kepala Madrasah Aliyah Negeri 2 Bulukumba berjalan dengan baik meskipun masih perlu ditingkatkan agar instruksional kepala madrasah lebih efektif lagi.

Raden Bambang Sumarsono dalam penelitiannya mengungkapkan bahwa keberhasilan kepala sekolah sebagai pemimpin pembelajaran antara lain: (1) sebagai penyedia sumber daya; (2) sebagai sumber instruksional terlihat dalam memajukan kondisi kelas yang efektif untuk menunjang hasil belajar, mendorong guru untuk menggunakan berbagai macam metode dan strategi pembelajaran; (3) 
sebagai komunikator, dapat menyampaikan visi dan misi secara jelas, memahami tujuan sekolah serta mampu menerjemahkan, membina hubungan yang efektif dengan para pemangku kepentingan; dan (4) kehadirannya bermakna artinya bahwa kepala sekolah mampu berinteraksi dan mampu mempengaruhi seluruh warga sekolah.(Raden Bambang Sumarsono, 2016).

Kepemimpinan intruksional harus dapat menyediakan sumber daya utamanya sumber daya manusia yang mampu memberikan perubahan secara signifikan di Madrasah Aliyah Negeri 2 Bulukumba. Sumber daya manusia itu adalah akademisi. Kepala madrasah sedapat mungkin melakukan kerja sama dengan kampus untuk kegiatan bersifat akademis di madrasah seperti pelatihan dan pengawasan internal.

Ada tiga keterampilan dasar yang harus dimiliki oleh kepala madrasah utamanya untuk kepentinangan pengembangan SDM di Madarsah yaitu: 1) Keterampilan teknis (Technicall Skill), 2) Keterampilan melakukan hubunganhubungan kemanusiaan (Human Skill), 3) Keterampilan konseptual (Sudarwan Danim, 2010:72).

Poin b tersebut bukan hanya hubungan manusia antara warga Madrasah tetapi perlu ekspansi hubungan utamaya untuk kepentingan pengembangan mutu pendidikan di Madrasah seperti kerjasama dengan kampus untuk pengawasan dan pelatihan internal di Madrasah.

Berdasarkan uraian tersebut maka peneliti menyimpulkan bahwa Kepemipinan instruksional Kepala Madrasah Aliyah Negeri 2 Bulukumba sudah berjalan baik tetapi masih perlu inovasi dalam melakukan kegiatan-kegiatan akademik dengan melibatakan akademisi dari kampus seperti Universitas Islam Negeri Alauddin Makassar dan Uiniversitas Negeri Makassar.

\section{Strategi Kepemimpinan Intruksional yang diterapkan Kepala Madrasah di Madrasah Aliyah Negeri 2 Bulukumba}

Kepala Madrasah Aliyah Negeri telah melaksanakan tugasnya dengan baik dengan startegi yang baik pula terbukti banyaknya prestasi siswa di Madrasah Aliyah Negeri 2 Bulukumba. Salah satunya Cerdas Cernat UIN 2018 untuk MA/SMA/SMK se-Sulawesi Selatan meraih juara II. Prestasi tersebut dapat meningkat jika kerjasama dengan melibatkan kampus dalam supervisi dan pelatihan internal Madrasah sebagai bagian dari strategi untuk meningkatkan mutu pendidikan di Madrasah.

Penelitian Puslitbang Pendidikan Agama dan Keagamaan Balitbang dan Diklat Kemenag menemukan kebijakan inovatif untuk meningkatkan mutu penyelenggaraan pendidikan di MTsN Bukit Raya Pekanbaru, dikelompokkan dalam 5 bagian.

a. SDM pendidik dan tenaga kependidikan. Untuk meningkatkan kompetensi guru dan tenaga kependidikan MTsN Bukit Raya, melakukan kerja sama dengan beberapa instansi untuk memberikan pelatihan-pelatihan bagi guru dan tenaga kependidikan. 
b. Bekerja sama dilakukan dengan Dinas Pendidikan, Kementerian Agama, Lembaga Peningkatan Mutu Pendidikan (LPMP) Provinsi Riau dan Universitas yang ada di Pekanbaru. Kerja sama tersebut memberikan kesempatan kepada guru dan tenaga kependidikan untuk melanjutkan pendidikan yang lebih tinggi; mengerakkan MGMP; Kepala Madrasah mendukung kemajuan teknologi (Melek Iptek) dengan menyediakan jaringan internet kepada guru-guru.

c. Meningkatkan kerja sama dengan orang tua, melibatkan orang tua dalam mensukseskan program adiwiyata; melibatkan orangtua dalam pendanaan untuk menyukseskan program adiwiyata yang sudah terlaksana dalam kurun waktu 6 bulan; rencana pengembangan kelas unggulan di mana sudah dilaksanakan seleksi siswa yang diambil dari SD dan MI se-Kota Pekanbaru peringkat 10 besar setiap semester.

d. Menghidupkan kembali kegiatan Kelompok Kerja Madrasah (KKM) melalui MTsN Bukit Raya sebagai pusat KKM; pelatihan guru mata pelajaran dilakukan minimal 1 kali dalam 6 bulan; pembuatan soal ujian semester sekolah; anggota KKM memberikan laporan setiap bulan ke MTsN Bukit Raya Pekanbaru.

e. Menjaga mutu prestasi siswa dengan menyaring siswa yang berprestasi untuk dibina oleh guru mata pelajaran tertentu dalam jangka waktu tertentu; program Kelas Bina Prestasi untuk mempersiapkan siswa menghadapi olimpiade; proses dalam prekrutan diadakan seleksi perkelas; siswa dibimbing oleh guru mata pelajaran yang professional; mendatangkan tenaga pembimbing dari universitas terkemukan di Riau (bergelar Dr dan Prof). (NU online, disadyr pada tanggal 31 Juli 2019).

Poin dari kebijakan Kepala MTsN Bukit Raya Pekanbaru dengan melakukan kerjasama dengan pihak kampus itu bisa dilakukan Madrasah Aliyah Negeri 2 Bulukumba.

Berdasarkan uraian di atas maka peneliti menyimpulkan bahwa Kepala Madrasah telah melakukan strategi yang baik untuk meningkatkan mutu pendidikan di Madrasah Aliyah Negeri 2 Bulukumba. Tetapi hal tersebut dapat ditingkatkan dengan melibatkan atau bekerjasama dengan kampus untuk memajukan dan meningkatkan mutu pendidikan di Madrasah Aliyah Negeri 2 Bulukumba.

\section{Peluang dan Tantangan Kepala Madrasah dalam Menerapkan Kepemimpinan Intruksional di Madrasah Aliyah Negeri 2 Bulukumba.}

Ada beberapa peluang Kepala Madrasah Aliyah Negeri 2 Bulukumba yaitu: 1) Dukungan maksimal kepada tenaga pendidik dan kependidikan dalam rangka untuk peningkatan mutu pendidikan, 2) Madrasah memiliki mitra yang dapat bekerjasama untuk peningkatan mutu pendidikan di Madrasah Aliyah Negeri 2 Bulukumba, 3) Penganggaran peningkatan kompetensi SDM di Madarasah Aliyah Negeri 2 Bulukumba. Kemudian tantangan Kepala adrasah Aliyah Negeri 2 Bulukumba yaitu 
1) Porsi anggaran terbagi sehingga tidak dapat secara maksimal dalam mengembangkan dan meningkatkan SDM di Madrasah, 2) Mitra MadarasahAliyah Negeri 2 Bulukumba belum menjalin kemitraan dengan pihak kampus yang dinilai dapat mendorong peningkatan mutu SDM, 3) Tenaga pendidik dan tenaga kependidikan belum secara maksimal melakukan upaya secara individu untuk meningkatakan kinrjanya.

Poin a dan b sangat penting dalam mewujudkan pendidikan yang bermutu. Kepala madrasah harus mampu menyiasati untuk mendapatkan tambahan anggaran untuk memajukan madrasah khususnya untuk kegiatan peningkatan mutu SDM. Peningakatan mutu SDM harus melibatkan pihak kampus utamanya dalam pembimbingan khusus siswa yang berbakat.

Siswa yang berbakat di bidang IT maka dosen IT yang akan menjadi pembimbing khususnya, siswa yang berbakat matematika maka dosen matematika yang akan membimbingnya, siswa memiliki bakat penceramah maka bisa bekerja sama dengan lembaga dakwah kampus.

Berdasarkan uraian di atas maka Kepemimpinan intruksional Kepala Madrasah dapat memaksimalkan peluang dan menjawab tantangan dengan melibatkan pihak kampus sebagai inovasi peningkatan mutu SDM.

\section{PENUTUP DAN SIMPULAN}

Berdasarkan uraian, hasil deskripsi dan interpretasi data penelitian, maka peneliti dapat mengemukakan beberapa kesimpulan akhir dari penelitian ini sebagai berikut:

a. Kepemimpinan intruksional Kepala Madrasah Aliyah Negeri 2 Bulukumba berjalan dengan baik tetapi perlu adanya inovasi kebijakan yaitu menghadirkan pihak kampus dalam kegiatan pengawasan dan pelatihan internal madrasah

b. Strategi Kepemimpinan Instruksional Kepala Madrasah yang diterapakan adalah memaksimalkan supervisi lingkup madrasah, pelatihan lingkup madrasah dan mengikutkan guru dan tenaga kependidikan pelatihan/workshop/seminar untuk meningkatkan mutu pendidikan di madrasah secara kuantitas tetapi secara kualitas belum maksimal karena dalam pelatihan dan pengawasan internal belum maksimal karena belum melibatkan pihak ahli di bidangnya yaitu pihak kampus.

c. Peluang dan tantangan Kepala Madrasah Aliyah Negeri 2 Bulukumba dalam menerapkan kepemimpinan instruksioanal adalah sebagai berikut:

Peluang:

1. Dukungan maksimal kepada tenaga pendidik dan kependidikan dalam rangka untuk peningkatan mutu pendidikan

2. Madrasah memiliki mitra yang dapat bekerjasama untuk peningkatan mutu pendidikan di Madrasah Aliyah Negeri 2 Bulukumba.

3. Penganggaran peningkatan kompetensi SDM di Madarasah Aliyah Negeri 2 Bulukumba. 
Tantangan:

1. Porsi anggaran terbagi sehingga tidak dapat secara maksimal dalam mengembangkan dan meningkatkan SDM di Madrasah.

2. Mitra Madarasah Aliyah Negeri 2 Bulukumba belum menjalin kemitraan dengan pihak kampus yang dinilai dapat mendorong peningkatan mutu SDM.

3. Tenaga pendidik dan tenaga kependidikan belum secara maksimal melakukan upaya secara individu untuk meningkatakan kinrjanya.

\section{DAFTAR PUSTAKA}

Abdullah Munir. 2008. Menjadi Kepala Sekolah Efektif. Ar-Ruzz Media, Yogyakarta

Andang. 2014. Manajemen \& Kepemimpinan Kepala Sekolah. Yogyakarta:Ar Ruzz Media

E. Mulyasa. 2003. Menjadi Kepala Sekolah Profesional dalam Konteks Menyukseskan MBS dan KBK. Bandung: PT Remaja Rosdakarya

E. Mulyasa. 2004. Kurikulum Berbasis kompetensi. Bandung: PT Remaja Rosdakarya

E. Mulyasa. 2013. Kurikulum Berbasis kompetensi. Bandung: PT Remaja Rosdakarya Kartini Kartono. 2010. Pemimpin dan Kepemimpinan. Jakarta: Rajawali.

Lexy Moleong. 2006. Metodologi Penelitian Kualitatif Cet. II; Bandung: Remaja Rosdakarya.

Muhammad Saroni. 2006. Manajemen Sekolah. Jogjakarta: Ar-Ruzz.

NU online. 2019. Kebijakan Inovatif Kepala Madrasah Penentu Kualitas Madrasah, link: https://mitra.nu.or.id/post/read/73482/kebijakan-inovatif-kepalamadrasah-penentu-kualitas-madrasah di sadur pada tanggal 31 Juli 2019

Raden Bambang Sumarsono. 2019. Upaya Peningkatan Mutu Sekolah Melalui Penguatan Peran Kepemimpinan Pembelajaran Oleh Kepala Sekolah, di sadur dari web jurnal Jurusan Administrasi Pendidikan Fakultas IImu Pendidikan Universitas Negeri Malang http://ap.fip.um.ac.id/wpcontent/uploads/2016/03/41-Raden-Bambang-Sumarsono.pdf pada tanggal 31 Jui 2019

Peraturan Menteri Agama Republik Indonesia No. 582017 tentang Kepala Madrasah.

Soekarto Indra Fachrudi dkk. 1983. Pengantar Kepemimpinan Pendidikan. Surabaya: Usaha Nasional

Soerjono Soekamto. 2003. Sosiologi Suatu Pengantar. Jakarta: Raja Grafindo Persada.

Sulistyorini. 2006. Manajemen Pendidikan Islam. Surabaya: elKaf.

Supardi.2013. Sekolah Efektif; Konsep Dasar dan Praktiknya. Jakarta: Raja Grafindo Persada. 
RINA SULAEHA

Syarwan Ahmad. 2014. Problematika Kurikulum 2013 Dan Kepemimpinan Instruksional Kepala Sekolah. Jurnal Pencerahan Volume 8, Nomor 2, 2014.

Undang-Undang RI. No. 20 tahun 2003. Sistem Pendidikan Nasional dan Penjelasannya. Bandung: PT. Citra Umbara.

Wahjo Sumidjo.2003. Kepemimpinan Kepala Sekolah; Tinjauan Teoritik dan Permasalahannya. Jakarta: Raja Grafindo Persada. 